Available online at website :

http:/ / e-journal.adpgmiindonesia.com/index.php/jmie

JMIE: Journal of Madrasah Ibtidaiyah Education, 4(1), 2020, 86-99

\title{
MENERAPKAN SIKAP DAN PERILAKU YANG BERPRINSIP PADA BHINNEKA TUNGGAL IKA DI ERA 4.0 DALAM PEMBELAJARAN K13 DI MI/SD KELAS IV
}

\author{
Arifian Dwi Astuti ${ }^{1)}$, Mila Wati Nur Farida ${ }^{2}$, Anis Fuadah Z ${ }^{3)}$ \\ Universitas Islam Negeri (UIN) Syarif Hidayatullah Jakarta 1),2),3)
}

Email: arifiandwi.astuti18@mhs.uinjkt.ac.id ${ }^{1}$,mila.wnf18@mhs.uinjkt.ac.id2), anisfuadah.zuhri@uinjkt.ac.id ${ }^{3)}$

Naskah diterima : 28 Januari 2020, direvisi : 28 April 2020, disetujui : 30 April 2020

\begin{abstract}
This research aims to explain the importance of Bhinneka Tunggal Ika values in the implementation of daily life, especially in the 4.0 era. In this research, the authors focus on the attitudes and behavior of a person to respect the diversity that is owned by Indonesia, especially in the era of the industrial revolution 4.0 which changed many people's behavior to deviate due to technological sophistication. Researchers used data collection techniques in the form of literature of review. Researchers receive references from various sources, especially from books, journals, and other papers. In writing, researchers must understand the various sources that have been obtained and analyze them, so as to get a conclusion. The results showed that each ethnic, race, religion, and culture that exist have different languages, and customs. Therefore, Indonesia has a motto that says Unity in Diversity, which means different but still one. Unity in Diversity is applied by Indonesia to reflect the value of unity and unity of nation which aims to maintain the integrity of the Unitary State of the Republic of Indonesia. Understanding the values of Unity in Diversity in multicultural societies is used as a pillar of nationalism, because it contains the value of patriotism embodied with tolerance and justice. From the explanation above it can be concluded that, we as Indonesian citizens must have mutual respect, even though we have differences in everything, but we have the same goal, namely for Indonesia, and the value of Unity in Diversity must be applied so that attitudes are not eroded by developments era.
\end{abstract}

Keywords: Unity in Diversity, values, attitude.

Pengutipan: . Astuti, Arifian Dwi, dkk. (2020). Menerapkan Sikap dan Perilaku yang Berprinsip pada Bhinneka Tunggal Ika di Era 4.0 dalam Pembelajaran K13 di MI/SD Kelas IV. JMIE: Journal of Madrasah Ibtidaiyah Education,4(1), 86-99. jmie.v4i1.173. 


\section{PENDAHULUAN}

Negara Kesatuan Republik Indonesia merupakan negara multikultur. Indonesia memiliki keragaman dalam hal kebudayaan, ras, suku, bangsa, agama dan lainnya. Keberagaman yang dimiliki Indonesia menggambarkan sebuah kekayaan sumber daya manusia dan keunikan Indonesia. Hal ini adalah contoh dari jutaan kekayaanyang Indonesia miliki, selain kekayaan alamnya yang berlimpah. Multikultur merupakan kesatuan budaya, ras, suku, agama, dan bahasa yang terdapat di Indonesia. Keseluruhan tersebut memiliki perbedaan antara yang satu dengan yang lainnya. Sebagian masyarakat menganggap bahwa perbedaan ini dapat menimbulkan berbagai macam konflik, bahkan perpecahan bangsa. Hal ini disebabkan oleh banyaknya masyarakat yang belum mengerti bahwasannya dari perbedaan tersebut merupakan suatu hal yang menjadi ciri khas yang dapat membedakan daerah tertentu terhadap daerah lain nya. Konflik ini bisa terjadi jika salah satu suku atau daerah menganggap dirinya lebih tinggi dan yang lainnya lebih rendah. Hal ini tidak mencerminkan adanya nilai-nilai yang mencerminkan adanya prinsip bangsa.

Bhinneka Tunggal Ika merupakan prinsip hidup bangsa dan dikenal sebagai semboyan Indonesia. Semboyan tersebut mendeskripsikan tentang kesatuan dan keutuhan bangsa yang diciptakan dari sikap persatuan. Bhinneka Tunggal Ika memiliki makna yang berbeda-beda tetapi tetap satu jua. Dalam prinsip ini, terdapat nilai luhur yang tercantum juga pada nilai-nilai Pancasila yang merupakan falsafah kehidupan bangsa Indonesia. Nilai toleransi dan keadilan merupakan salah satu nilai yang tersirat dalam semboyan bangsa Indonesia. Sikap saling menghargai, memahami perbedaan, tenggang rasa, dan serta tidak melakukan diskriminasi atau membeda-bedakan seseorang bersadarkan status, karena hal ini dapat mempererat tali persaudaraan. Masyarakat Indonesia tidak akan terpecah-belah jika memegang prinsip ini dengan kuat, karena dalam semboyan dan falsafah bangsa tidak memihak salah satu kebudayaan, suku, ras, agama, atau bahasa, melainkan menyatukan seluruhnya menjadi sebuah kesatuan, yang memperkuat bangsa Indonesia.

Pemahaman nilai-nilai luhur yang terus menyurut dan rasa cinta tanah air yang meredup adalah salah satu pemicu terjadinya konflik. Perkembangan zaman pun menjadi salah satu faktor yang mendukung terpecahnya Indonesia. Era 4.0 yang kerap disebut era globalisasi dan era milenial adalah zaman berkembang pesatnya teknologi. Hadirnya teknologi dapat mempermudah aktivitas masyarakat, namun dengan adanya teknologi juga dapat membawa arus budaya asing ke dalam Indonesia menyebabkan nasionalisme masyarakat Indonesia menjadi mengendur. Hal ini terjadi karena banyak masyarakat Indonesia yang tidak memilah dampak dari adanya perkembangan zaman. Masyarakat Indonesia harus berpegang teguh terhadap prinsip dan falsafah bangsa, agar masyarakat mampu memilih dampak positif yang sesuai dengan keadaan dan situasi bangsa, dan dampak negatif yang dapat memperburuk keadaan bangsa. 
Berdasarkan latar belakang tersebut, maka penulis tertarik untuk mengkaji persoalan tentang bagaimana cara bersikap dan berperilaku yang berprinsip pada Bhinneka Tunggal Ika di era 4.0? Masalah tersebut dirumuskan oleh penulis dengan tujuan agar masyarakat Indonesia memiliki wawasan kebhinekaan, memahami arti dari perbedaan dan persatuan, mengetahui nilai-nilai yang terkandung dalam Bhinneka Tunggal Ika, serta bertujuan untuk membentuk masyarakat yang berperilaku yang sesuai dengan falsafah bangsa, agar tidak terjadi berbagai konflik dalam kehidupan Indonesia yang menyebabkan perpecahan bangsa.

\section{METODE}

Metode yang digunakan dalam kajian ini menggunakan metode studi pustaka. Pendekatan kepustakaan atau studi pustaka adalah serangkaian kegiatan yang meliputi pengumpulan data pustaka, membaca, mencatat, serta mengolah bahan penelitian. Teknik pengambilan data ini merupakan istilah lain dari kajian pustaka, landasan teori, atau tinjauan pustaka. Studi pustaka ini adalah metode penelitian di mana peneliti tidak harus turun langsung ke lapangan untuk bertemu dengan sumber. Metode studi pustaka dapat diperoleh dari datadata berdasarkan sumber perpustakaan. Peneliti dapat menganalisis tulisannya dengan membandingkan karya-karya tulisan orang lain, sehingga memperoleh data yang spesifik. Meskipun terlihat mudah, namun teknik studi pustaka memerlukan ketekunan yang tinggi untuk mencari sumber, membaca, mencatat, dan mengolah data agar sesuai dengan tujuan penulisan. Studi pustaka merupakan teknik pengambilan data yang bertujuan untuk memecahkan suatu masalah. Teknik ini pada dasarnya berpijak pada penelaahan kritis dan mendalam terhadap bahan-bahan pustaka yang relevan (Hermawan, 2019). Peneliti memperoleh referensi dari berbagai sumber, baik dari buku, jurnal, maupun karya tulis lainnya. Dalam proses menulis artikel ini, penulis mengumpulkan seluruh data yang berkaitan dengan tema bahasan yaitu mengenai sikap dan perilaku seseorang untuk menghormati keberagaman yang dimiliki oleh Indonesia, terutama di era revolusi industri 4.0. Kemudian, setelah memiliki sumber yang cukup, peneliti membaca secara mendalam, menganalisis data dari semua sumber yang dapat dipercaya, dan mendiskusikan mengenai hasil yang telah diperoleh, serta meringkasnya menjadi sebuah kesimpulan yang padat.

\section{HASIL DAN PEMBAHASAN}

Penelitian ini bertujuan untuk menjelaskan pentingnya nilai-nilai Bhinneka Tunggal Ika dalam pengimplementasian kehidupan sehari-hari, terutama di era 4.0. Pada era revolusi industri 4.0 ini mendatangkan dampak positif, seperti hal nya masyarakat dapat dengan mudah untuk berkomunikasi dan menerima informasi. Namun, kehadirannya juga membawa dampak negatif, terutama pada penurunan moral masyarakat, sehingga timbul perilaku menyimpang yang diakibatkan oleh banyaknya budaya asing yang masuk ke dalam Indonesia. Dari hasil 
penelitian dapat diketahui bahwasannya warga negara Indonesia harus berpegang teguh pada semboyan dan dasar negara Indonesia, serta harus saling menghormati dan menerima keragaman yang dimiliki oleh Indonesia. Hal yang sedemikian tersebut harus dilakukan, agar masyarakat tetap berperilaku yang mencerminkan semboyan bangsa dan menjaga keutuhan Negara Kesatuan Republik Indonesia agar tidak terpengaruh oleh perkembangan zaman.

Berikut ini merupakan pembahasan terkait hasil penelitian, di antaranya adalah sebagai berikut:

\section{Multikultural Indonesia}

Multikultural merupakan suatu istilah yang digunakan untuk memaparkan pandangan seseorang tentang keragaman yang ada di dunia. Multikultural juga bisa diartikan menjadi pembanding kebudayaan yang ada terhadap kebudayaan yang lain. Peneliti memfokuskan bahasannya pada keberagaman yang ada di Indonesia. Hal ini didukung oleh beberapa indikator, seperti banyaknya kebiasaan atau adat-istiadat, suku, budaya, ras, dan agama yang ada di Indonesia. Multikultural Indonesia ialah suatu istilah yang digunakan untuk menggambarkan pandangan seseorang tentang keragamaan yang dimiliki oleh negara Indonesia. Indonesia merupakan bagian dari negara yang ada didunia yang memiliki ciri multikultural terbanyak dan terbesar di dunia. Keadaan ini bisa dilihat dari perihal status sosial, budaya, maupun letak wilayah Indonesia yang sangat luas dan beragam disebut dengan multickultural terbesar, bisa dibuktikan dari sejumlah besar sekumpulan orang atau kelompok, budaya, etnis, agama, adat istiadat, dan lain sebagainya yang memiliki sifat plural dan heterogen (bermacam-macam). (Lestari, 2015).

Keberagaman pada suatu aspek kehidupan ialah suatu takdir bagi bangsa Indonesia yang tidak akan dan tidak bisa untuk dihindari. Hal ini harusnya bisa disyukuri oleh rakyat Indonesia (Endang Susilowati, 2018). Dari keanekaragaman masyarakat setidaknya ada dua ciri-ciri yang unik dan bisa dilihat pada Indonesia, pertama dilihat secara horizontal atau mendatar, Indonesia memiliki karakter dengan adanya kesatuan-kesatuann sosial yang bersumber pada perbedaan ras, suku bangsa, adat, agama dan perbedaan kedaerahan. Sedangkan yang kedua bisa dilihat secara vertikal atau tegak, Indonesia memiliki ciri yang ditandai dengan adanya perbedaan-perbedaan vertikal antara lapisan atas dan lapisan bawah yang agak tajam.

Pluralitas dan heterogenitas yang tampak dan nyata adanya pada masyarakat Indonesia yang digabung dengan prinsip keutuhan dan kesatuan bangsa atas dasar sikap persatuan yang dikenal sebagai semboyan Bhinneka Tunggal Ika. Semboyan tersebut memiliki makna, walaupun Indonesia berbhinneka, namun tetap melekat pada kesatuan. Hal ini membuktikan bahwasannya Indonesia memiliki keunikan tersediri nya, yaitu bersatu dalam suatu daya dan kerukunan beragama, berbangsa dan bernegara yang seharusnya diingat dan disadari. Akan tetapi, keberagaman ini dapat membawa berbagai macam perpecahan. Dengan keadaan ini, 
tentunya masyarakat Indonesia harus dapat menyadari dan memahami tentang adanya keberadaan perbedaan, dan masyarakat harus menanggapinya dengan sikap toleransi.

Sejak berdirinya negara Indonesia, para pendahulu negara memaksudkan persatuan di negara ini untuk mewujudkan masyarakat yang bisa menghargai adanya perbedaan di Indonesia, termasuk perbedaan adat, agama, ras, suku dan yang lainnya. Dengan adanya perbedaan ini bisa terjadi perpecahan yang timbul karena adanya rasa tersinggung, dan lain sebagainya. Maka dari itu perlu adanya usaha dan upaya menciptakan suatu hal yang bisa menenangkan dan bisa meredamkan dari permasalahan yang timbul (Salim, 2017). Berikut ini adalah contoh keberagaman nusantara yang mencerminkan bahwa perilaku masyarakat multikultural Indonesia sangat menghargai perbedaaan, bahkan terdapat akulturasi yang damai di dalam adat-istiadatnya (R. Rizki, 2015);

\section{Tabel 1. Multikultural Indonesia}

\begin{tabular}{|c|c|c|c|}
\hline No & Provinsi & Suku & Adat Istiadat \\
\hline 1. & Jawa Tengah & Jawa & $\begin{array}{l}\text { Sekaten, merupakan perilaku masyarakat jawa } \\
\text { tengah untuk upacara dalam rangka memperingati } \\
\text { maulid nabi Muhammad SAW }\end{array}$ \\
\hline 2. & Kalimantan Barat & Dayak & $\begin{array}{l}\text { Naik Dango, merupakan perilaku masyarakat } \\
\text { Kalimantan Barat yang diadakan setiap tahun } \\
\text { untuk mengungkapkan rasa syukur terhadap sang } \\
\text { pencipta atas hasil panen padi yang diperoleh. }\end{array}$ \\
\hline 3. & Bali & Bali & $\begin{array}{l}\text { Melasti, merupakan perilaku masyarakat Bali yang } \\
\text { diadakan setiap } 3 \text { hari sebelum nyepi, dengan } \\
\text { tujuan untuk menyucikan diri. }\end{array}$ \\
\hline 4. & DKI Jakarta & Betawi & $\begin{array}{l}\text { Nujuh Bulan, merupakan perilaku masyarakat } \\
\text { Jakarta yang dilakukan setiap bulan ke- } 7 \text { kehamilan } \\
\text { dengan tujuan mengharapkan agar anak selamat } \\
\text { dan mensyukuri nikmat tuhan. }\end{array}$ \\
\hline 5. & Sumatera Barat & Minang & $\begin{array}{l}\text { Tabuik, merupakan perilaku masyarakat Sumatera } \\
\text { Barat yang diselenggarakan secara turun menurun } \\
\text { pada tanggal } 10 \text { Muharram dengan tujuan untuk } \\
\text { memperingati kematian cucu Nabi Muhammad, } \\
\text { Husein. }\end{array}$ \\
\hline 6. & Papua & Dani & $\begin{array}{l}\text { Pesta Bakar Batu, merupakan perilaku masyarakat } \\
\text { Papua dalam rangka menggelar pesta untuk } \\
\text { menyambut pernikahan, kelahiran maupun } \\
\text { merayakan kemenangan perang. }\end{array}$ \\
\hline
\end{tabular}




\section{Nilai nilai Bhinneka Tunggal Ika}

Dengan adanya peristiwa Sumpah Pemuda pada 28 Oktober 1928 ini melahirkan suatu tekad yang bulat oleh para pemuda seluruh rakyat Indonesia yang memiliki perbedaan suku, agama, daerah, bahasa dan organisasi mendukung tekad ini untuk mempersatukan bahasa dan persatuan yang sebagaimana arti yang terkandung dalam semboya dan prinsip bangsa. Bahasa sansekerta merupakan awal mulanya uncul kalimat Bhinneka Tunggal yang terdiri dari 3 kata yaitu Bhinneka Tunggal dan Ika. Jika diartikan satu persatu dari kata Bhinneka Tunggal Ika memiliki arti didalamnya bahwasannya Bhinneka artinya berbeda-beda, Tunggal artinya satu dan Ika artinya itu. Bhinneka Tunggal Ika memiliki arti berbeda-beda tetap satu jua. Bhinneka Tunggal Ika ialah keberagaman dalam kesatuan. Kesatuan merupakan suatu yang diharapkan oleh rakyat atau cita-cita untuk mengangkat dan menempatkan elemen perbedaan yang ada dalam keanekaragaman bangsa Indonesia (Setyaningsih, 2019). Kesatuan merupakan sebuah usaha yang dilakukan untuk menciptakan tempat atau wadah yang bisa menyatukan perbedaan.

Bhinneka Tunggal Ika ini merupakan semboyan yang dimiliki oleh Indonesia. Semboyan ini tertulis di dalam lambang negara Indonesia, yaitu kaki burung garuda Pancasila. Bhinneka Tunggal Ika ialah pernyataan jiwa dan semangat bangsa Indonesia yang mau mengakui keadaan yang sebenarnya yang masih beragam, tetapi masih menjunjung tinggi kesatuan. Jadi, dapat disimpulkan bahwasannya Indonesia memiliki keragaman yang tentunya memiliki perbedaan-perbedaan, namun pada intinya satu yaitu mencapai tujuan bersama bangsa Indonesia.

Dengan adanya perbedaan tersebut, diharapkan rakyat Indonesia menanggapi nya dengan sikap yang baik. Secord dan Backman menjelaskan bahwa sikap adalah tindakan, perasaan, dan pemikiran seseorang yang selalu terjadi dan dilakukan berulang-ulang dalam kehidupan pribadi maupun di lingkungan masyarakat (Rafiah, 2017). Sikap memiliki fungsi diantaranya yaitu, sikap digunakan sebagai media dan sarana untuk menyesuaikan diri, pengatur terhadap tingkah laku, pengatur pengalaman, pernyataan kepribadian.

Suatu nilai bisa diterapkan dalam kehidupan sehari-hari menjadi sebuah sikap. Jika pada Bhinneka Tunggal Ika, masyarakat Indonesia harus memiliki sikap yang mendukung adanya Bhinneka Tunggal Ika. Adapun, nilai-nilai Bhinneka Tunggal Ika, nilai merupakan elemen yang memuat pertimbangan yang bisa membawa pemikiran seseorang mengenai hal yang baik, benar ataupun hal yang diinginkan dan nilai tersebut bersumber dari agama maupun tradisi humanistic (Setyaningsih, 2019). Berdasarkan pemaparan diatas, dapat disimpulkan bahwasannya nilai merupakan suatu elemen, keyakinan yang menjadi sebuah patokan dan mampu mempengaruhi perilaku untuk menentukan pilihannya. 
Adapun dengan adanya Bhinneka Tunggal Ika mampu melahirkan nilai-nilai yang ada dan bisa dirasakan bagi individu maupun orang lain. Nilai yang dimaksud ialah nilai sebagai berikut:

\section{Toleransi}

Toleransi merupakan nilai yang penting dari kebhinnekaan yang digunakan sebagai keniscayaan. Toleransi berasal dari bahasa Latin yaitu "tolenrantia" yang berarti kelonggaran, kelembutan hati, kesabaran dan keringanan. Toleransi bisa dimengerti sebagai suatu sikap juga gagasan yang menjelaskan berbagai kemungkinan. Terdapat lima hal yang menjadi inti dari toleransi. Pertama, bisa menerima suatu perbedaan agar hidup dijalani dengan keadaan yang damai. Kedua, memutuskan kebhinnekaan menjadi perbedaan, tidak perlu adanya penyergaman lagi. Ketiga, menciptakan moral yang bisa menerima dan mengerti bahwasannya setiap orang memang memiliki hak, biarpun dalam praktik dalam kehidupan belum menarik simpati dari orang lain. Keempat, menerapkan keterbukaan terhadap yang lain seperti rasa ingin tahu, menghargai, mau mendengarkan dan mau belajar dari orang lain. Kelima, adanya dukungan yang energik terhadap adanya perbedaan yang menenkankan pada aspek otonomi (Nengah, 2018). Pada intinya toleransi bukan hanya membenarkan apa yang menjadi keyakinan, melainkan lebih kepada sikap menghargai dan sikap adnya pengakuan terhadap keyakinan masing-masing.

2. Nilai Keadilan

Kata adil berasal dari bahsa Arab yang berarti adl yang memiliki arti sama atau seimbang. Adil memiliki beberapa macam-macam makna yang berbeda yaitu berarti suatu kualitas yang fair, sebagai suatu tindakan yang menjalanakn hukum atau tindakan yang bisa menentukan hak dan ganjaran, dan orang yang memiliki hak untuk membentuk persyaratan. Keadilan merupakan suatu norma dasar hubungan sosial yang mampu menghilangkan dan mencegah segala bentuk sifat keasingan. Keadilan artinya memberikan apa kepada saya dan apa yang saya punya" (Herawati, 2014). Keadilan sosial bagi seluruh rakyat Indonesia ialah dasar ideologi Negara Indonesia yang mencerminkan adanya nilai keadilan pada bangsa.

Keadilan juga berarti adanya sebuah pengakuan dan perlakuan yang sama antara hak maupun kewajiban. Apabila kita mengakui adanya hak pada hidup kita, maka begitupun sebaliknya kita harus mempertahankan hak untuk hidup, bekerja keras dengan tidak mengganggu orang lain, tidak merugikan orang lain. Karena pada dasarnya orang lain memiliki kesamaan yang kita juga miliki. Kesamaan tesebut adanya hak dan kewajiban, dengan adanya hak dan kewajiban kita harus bisa saling menghargai antara hak dan kewajiban yang dimiliki oleh orang lain, dengan tidak membeda-beda kan suku, agama, ras, dan adat. 


\section{Implementasi Nilai-Nilai Bhinneka Tunggal Ika di Era 4.0}

Implementasi nilai-nilai Bhinneka Tunggal Ika di era 4.0 adalah suatu usaha yang tidak dapat dianggap sebelah mata. Usaha untuk mewujudkan masyarakat Indonesia yang dapat menghargai perbedaan bukanlah usaha yang sangat mudah, karena setiap masyarakat memiliki pandangannya sendiri. Penerapan nilai-nilai Bhinneka Tunggal Ika dapat dilaksanakan dengan cara meningkatkan sifat nasionalisme pada masyarakat. Nasionalisme dapat ditumbuhkan kembali kepada masyarakat melalui beberapa momentum yang berhubungan erat dengan bangsa. Selain itu, pendidikan juga merupakan salah satu wadah untuk meningkatkan sifat nasionalisme. Pendidikan adalah sebuah usaha yang dilakukan secara sadar dan telah direncanakan dengan matang, yang bertujuan untuk mengembangkan potensi yang dimiliki oleh peserta didik agar mereka memiliki pemahaman spiritual yang baik, dapat mengendalikan emosi dari dalam dirinya, menjadi pribadi yang cerdas, berakhlak mulia dan berbudi pekerti yang luhur, serta memiliki kemampuan yang tangkas untuk menghadapi kehidupan dalam bermasyarakat, berbangsa dan bernegara (Neolaka, dan Grace Amalia, 2017). Pendidikan dapat dijadikan tempat untuk mempelajari segala hal yang berhubungan dengan bangsa Indonesia. Nilai-nilai yang terkandung dalam Bhinneka Tunggal Ika akan dipelajari lebih dalam pada bidang studi pendidikan kewarganegaraan. Melalui proses pendidikan kewarganegaraan, nilai yang ada dalam Bhinneka Tunggal Ika akan dijelaskan lebih rinci, mulai dari nilai toleransi dan nilai keadilan. Ada pun cara lain dalam menumbuhkan semangat nasionalisme, yaitu dengan membaur terhadap masyarakat. Dengan cara tersebut, masyarakat akan memahami arti dari Bhinneka Tunggal Ika, karena dengan terjun dalam dunia yang berbeda latar belakang, masyarakat akan menumbuhkan rasa saling mengerti satu sama lain, masyarakat akan memahami arti dari hidup bersama dalam perbedaan, hidup bersama dalam kerukunan, saling bekerjasama dalam menyelesaikan masalah, saling memberi rasa aman, adil, dan mewujudkan rasa saling menghargai kemajemukan yang ada di Indonesia (Puspita, Rianny dan Dikdik Baehaqi Arif, 2014).

Indonesia adalah negara yang dikenal dengan negara yang memiliki kekayaan bahasa, agama, suku, budaya serta adat istiadat. Dengan keberagaman yang dimiliki, maka masyarakat Indonesia harus memiliki rasa toleransi. Toleransi merupakan sikap tenggang rasa, saling menghargai, tidak membeda-bedakan seseorang berdasarkan pandangan, kepercayaan, suku, ras, maupun agama. Sikap toleransi dapat diamalkan daam kehidupan-kehidupan bermasyarakat seperti mengamalan sikap saling menerima perbedaan, mengakui hak orang lain, menghargai keberadaan orang lain, serta menerima keberagaman budaya dan adat istiadat (Akhyar, Zainul, dkk., 2015). Keadilan merupakan sikap seseorang yang meletakkan sesuatupada tempatnya, bersikap yang sama terhadap orang lain, dan tidak membeda-bedakan satu dengan yang lain. Sikap adil dapat diterapkan dengan beberapa perilaku, seperti tidak memihak oleh pihak manapun, menempatka sesuatu pada tempatnya, menghargai orang sesuai dengan kerja kerasnya, menghormati hak orang lain, tidak membela berdasarkan kesamaan, 
dan bijaksana (Husna, 2012). Dengan adanya sikap toleransi dan keadilan, maka terciptalah kerukunan. Hidup rukun merupakan kondisi hidup yang tentram, aman, damai, nyaman, saling menyayangi dan menghormati, tanpa memandang perbedaan. Implementasi hidup rukun, dapat digambarkan dengan rasa saling menghormati dan menyayangi, mempererat hubungan kekeluargaan, saling kerja sama, membantu teman yang dalam kesusahan, mengikuti acaraacara yang ada di lingkungan, membiasakan diri untuk sopan santun, serta bersikap dan memperlakukan orang lain sama seperti memperlakukan diri sendiri (Purwaningsih, 2012).

\section{Bersikap dan Berperilaku yang Berprinsip pada Bhinneka Tunggal Ika di Era 4.0}

Bersikap dan berperilaku yang berprinsip pada Bhinneka Tunggal Ika di era 4.0 merupakan pola bersikap dan perilaku yang berdasarkan pada nilai Bhinneka Tunggal Ika yang dilakukan di zaman yang berkaitan dengan perkembangan teknologi, dan era globalisasi. Era revolusi industri 4.0 hadir membawa membawa banyak perubahan, mulai dari teknologi, internet, dan lainnya. Kehadiran internet dapat menimbulkan efek positif dan juga efek negatif. Dampak positif dari perkembangan era adalah kemudahan dalam komunikasi, dan transportasi. Namun, dari beberapa dampak positif tersebut, perkembangan era ini memiliki dampak negatif yang cukup signifikan. Hal tersebut dikarenakan oleh banyaknya budaya yang masuk ke Indonesia. Terdapat beberapa kasus yang terjadi, seperti kasus perundungan di dunia maya (cyber bullying), perilaku adu domba di media sosial sehingga banyak pro dan kontra masyarakat, perilaku menista agama sehingga menimbulkan perpecahan kelompok, bahkan kasus pelecehan(Septiana, 2019). Oleh karena itu, masyarakat harus memiliki pondasi yang kuat untuk menopang seluruh aktivitas masyarakat, agar sesuai dengan nilai luhur dan nilainilai Pancasila. Dalam sila-sila yang terdapat di Pancasila memiliki nilai yang sangat penting, sehingga Pancasila dijadikan sebagai pedoman Indonesia dalam berperilaku (Octavian, 2018).

Bhinneka Tunggal Ika adalah semboyan negara Indonesia yang memiliki pengertian "berbeda-beda tetapi tetap satu jua". Indonesia memiliki keberagaman adat-istiadat, suku, bahasa, ras, dan agama, namun tidak menjadikan masyarakat Indonesia menjadi terpecah belah, melainkan keberagaman tersebut menyatukan masyarakat Indonesia menjadi bangsa yang utuh, adil, toleran, dan damai (Pursika, 2019). Oleh karena itu, Bhinneka Tunggal Ika dijadikan prinsip masyarakat Indonesia untuk bersikap dan berperilaku. Tulisan Bhinneka Tunggal Ika yang termaktub dalam Kitab Sutasoma karya Mpu Tantular membuktikan bahwa semboyan ini telah diterapkan oleh para pendahulu (Subagio, 2013). Hal tersebut menguatkan kesadaran masyarakat mengenai keberagaman Indonesia. Pada era 4.0 kita harus berperan aktif untuk mengisi ruang-ruang kehidupan dengan perilaku yang berpedoman terhadap semboyan bangsa Indonesia. hal ini bertujuan agar keberadaan semboyan Bhinneka Tunggal Ika tetap ada dan tidak luntur tergerus oleh perkembangan zaman (Rosdalina, 2017). Berikut ini adalah 
sikap dan perilaku yang berprinsip pada Bhinneka Tunggal Ika di era 4.0, antara lain yaitu (Damanhuri, dkk., 2016):

1. Hidup rukun sesama masyarakat dengan cara saling toleransi.

2. Bersikap adil dan tidak melakukan tindak diskriminasi kepada sesorang atas dasar perbedaan status yang dimiliki, seperti perbedaan suku dan agama.

3. Tolong menolong antar sesame yang didasari dengan rasa ikhlas.

4. Menghargai dan menghormati seseorang, tanpa merendahkan derajat dan martabat orang lain.

5. Mengikuti berbagai kegiatan yang berhubungan dengan tanah air Indonesia, seperti bela negara, dan lain sebagainya.

6. Menggunakan media massa dengan bijak.

7. Memperkenalkan nilai-nilai Bhinneka Tunggal Ika di setiap aktivitas, dan mempekenalkan tentang arus era globalisasi.

8. Dapat membedakan pengaruh positif dan negatif dari adanya perkembangan era 4.0, dan berperilaku yang sesuai dengan nilai-nilai Pancasila.

9. Ikut berpartisipasi dalam rangka menjaga keutuhan moral bangsa, dan mengajak orang lain berpartisipasi untuk menepis budaya negatif dari pengaruh perkembangan zaman 4.0

\section{Menerapkan Sikap dan Perilaku yang Berprinsip pada Bhinneka Tunggal Ika di Era 4.0 dalam Pembelajaran K13 di MI/ SD}

Pendidikan merupakan salah satu wadah untuk membentuk karakter anak bangsa. Karakter yang dimiliki oleh generasi bangsa haruslah terpacu pada karakter yang mencerminkan atas dasar negara dan Bhinneka Tunggal Ika. Pembentukan sebuah karakter dalam diri seseorang sangat ditentukan saat masih anak-anak. Hal ini didukung oleh pendapat dari John Locke yang mengatakan bahwa pengalaman masa anak-anak sangat menentukan karakteristik seseorang ketika dewasa (Sit, 2017).

Konsep pendidikan Indonesia memiliki tujuan yang sejalan dengan pendapat John Locke. Oleh karena itu, kurikulum yang berlaku saat ini sangat mementingkan pendidikan karakter. Pendidikan karakter merupakan pendidikan yang dapat membantu siswa dalam perkembangan etika. Pendidikan karakter di Indonesia diciptakan untuk menciptakan lembaga pendidikan agar membina siswa nya menjadi anak yang memiliki etika yang baik dan bertanggung jawab. Pendidikan karakter lebih mengutamakan tiga komponen karakter yaitu pengetahuan tentang moral, perasaan tentang moral dan perbuatan bermoral. Kementerian pendidikan nasional telah merancang pendidikan karakter dan memiliki beberapa tujuan, seperti peningkatan pada poteni yang dimiliki peserta didik sebagai insan dan warga Negara yang cerdas dan berakhlak, mengembangkan perilaku juga kebiasaan yang dilakukan oleh 
peserta didik yang berprinsip pada nilai moral dan tradisir budaya yang berbasis keagamaan, dapat tertanaman sikap kepemimpinan dalam jiwa peserta didik, mengembangkan kemampuan yang dimiliki peserta didik, mengembangkan suasana lingkungan kehidupan sekolah yang jujur, tentram, serta dipenuhi dengan rasa kekuatan juga rasa cinta pada bangsa. Sasaran dari pendidikan karakter ialah kognitif, afektif, psikomotorik. Dalam penerapan kurikulum 2013, pendidikan karakter diintegrasikan di seluruh mata pelajaran, pada bahan Pendidikan Pancasila dan Kewarganegaraan (PPKn) di tingkat MI/SD yang kini dipadukan ke dalam pembelajaran tematik.

Dalam pembelajaran tematik kelas IV, tepatnya pada tema 6 subtema 1 Aku dan Citacitaku terdapat muatan pendidikan karakter yang merupakan penerapan sikap dari Bhinneka Tunggal Ika. Dalam tema tersebut dijelaskan bahwa seorang peserta didik harus memiliki sikap dan rasa syukur terhadap anugerah Tuhan Yang Maha Esa atas adanya beragam agama yang ada di kehidupan masyarakat, harus memiliki sikap toleransi dalam kehidupan karena adanya keberagaman agama di Indonesia (Kementerian Pendidikan dan Kebudayaan, 2017). Dalam menerapkan pendidikan karakter, buku tematik kelas IV tema 6 ini mengangkat cerita tentang cita-cita Patih Gajah Mada dalam mempersatukan pulau-pulau dan kerajaan-kerajaan yang ada saat itu. Patih Gajah Mada berhasil menyatukan beberapa pulau dan kerajaan yang masingmasing memiliki adat, agama, suku, bahasa, budaya, bahkan rumah adat yang berbeda-beda. Gajah Mada berhasil menyatukan beberapa daerah, seperti semenanjung Melayu, Sumatra, Jawa, Kalimantan, Sulawesi kecil, Bali, Maluku, Papua, bahkan hingga wilayah Darwin (Australia). Kumpulan wilayah yang telah disatukan oleh Gajah Mada tersebut dinamakan sebagai wilayah Nusantara. Pada buku ini, pembentukan karakter peserta didik dicerminkan dari nilai perjuangan Patih Gajah Mada tersebut. Sikap atau nilai yang dapat dipelajari dari kisah Patih Gajah Mada yaitu harus memiliki sikap toleransi dengan keberadaan umat beragama dalam masyarakat, harus percaya diri dan dapat menjadi pemimpin yang baik, serta harus mengharagai keberagaman (Kementerian Pendidikan dan Kebudayaan, 2017).

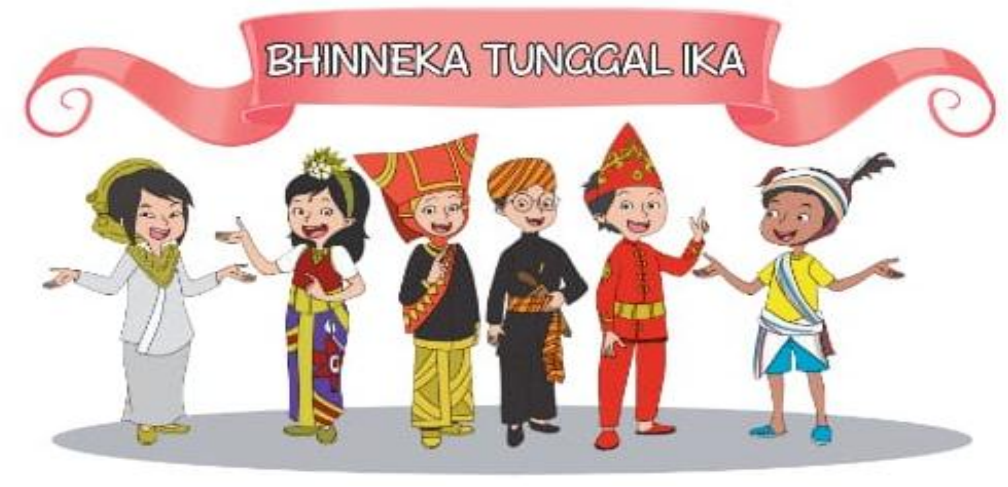

Gambar 1. Contoh keragaman di Indonesia

Sumber: (Kementrian Pendidikan dan Kebudayaan, 2017) 
Selain itu, muatan pendidikan karakter terdapat juga pada tematik kelas IV, tema 7 subtema 1 Keragaman Suku Bangsa dan Agama di Negeriku. Pada buku tersebut dijelaskan bahwa peserta didik harus bisa bisa memiliki rasa syukur terhadap anugerah Tuhan Yang Maha Esa atas dasar adanya keragaman bangsa yang berbentuk suku, social, serta budaya Indonesia yang memiliki keterikatan pada kesatuan, keutuhan, dan persatuan, peserta didik harus dapat menghargai perbedaan pendapat dengan orang lain, serta bertanggung jawab untuk melestarikan bahasa daerah (Kementerian Pendidikan dan Kebudayaan, 2016).

Dalam tema 7, buku tematik kelas IV menjelaskan mengenai Bhinneka Tunggal Ika secara detail dan terperinci. Pembahasannya diawali dengan pengenalan kalimat Bhinneka Tunggal Ika yang berarti berbeda-beda tetapi tetap satu. Kalimat Bhinneka Tunggal Ika yang memiliki makna bahwa Indonesia berbeda beda tetapi tetap satu. Kalimat Bhinneka Tunggal Ika terdapat pada lambang bangsa Indonesia, yaitu pada lambang burung Garuda Pancasila serta terdapat pada buku Sutasoma karya Mpu Tantular. Pembahasan selanjutnya yaitu mengenai kekayaan Indonesia seperti tarian yang dimiliki oleh daerah Indonesia, lagu has daerah, alat music yag terkenal pada daerah di Indonesia, serta kerajinan yang dihasilkan oleh masyarakat daerah Indonesia. Seluruh materi tersebut mengajarkan kepada peserta didik terhadap pentingnya Bhinneka Tunggal Ika, sehingga diharapkan siswa dapat mengerti dan memahami tentang keberagaman, menghargai keberagaman yang ada di Indonesia, dapat menerapkan sikap dan perilaku yang mencerminkan Bhinneka Tunggal Ika, serta mampu melestarikan kekayaan budaya yang dimiliki oleh Negara Kesatuan Republik Indonesia. Dengan diajarkannya Bhinneka Tunggal Ika di usia MI/SD, maka seseorang dapat memahami tentang keberagaman, dapat membentuk karakter anak yang baik, dan peserta didik dapat menerapkan sikap yang bercermin pada dasar negara dan Bhinneka Tunggal Ika sejak kecil, dewasa, hingga tua nanti. (Kementerian Pendidikan dan Kebudayaan, 2017)

\section{SIMPULAN}

Indonesia merupakan negara multikultural, di mana Indonesia memiliki banyak perbedaan, seperti halnya perbedaan keyakinan, bahasa, adat, suku dan lainnya. Namun, dari perbedaan tersebut jangan dijadikan sebagai suatu hal yang bisa memecah belah bangsa. Melainkan perbedaan dijadikan sebagai alat pemersatu bangsa. Keberagaman yang ada di Indonesia telah tercantum dalam Pancasila dan Bhinneka Tunggal Ika. Sebagai masyarakat, sudah semestinya mengamalkan nilai-nilai Bhinneka Tunggal dalam kehidupan sehari-hari, seperti toleransi dan keadilan. Toleransi dan keadilan bisa diaplikasikan dimana saja, seperti halnya dalam lingkungan keluarga, sekolah dan masyarakat, terutama era revolusi industri 4.0. Nilai-nilai tersebut dapat diterapkan melalui sikap dan perilaku yang berprinsip pada Bhinneka Tunggal Ika, seperti memfilter budaya yang masuk ke dalam kehidupan, memilah dampak positif dan negatif dari adanya perkembangan teknologi dan informasi, melestarikan budaya 
sopan dan santun, selalu memegang teguh nilai Pancasila, bersikap adil, saling menghargai, saling menghormati, tidak membeda-bedakan seseorang berdasarkan latar belakangnya, sehingga terwujudnya kehidupan yang aman, tentram dan damai. Sikap yang mencerminkan Pancasila dan Bhinneka Tunggal Ika, serta sikap yang mengutamakan persatuan harus dibudayakan, hal tersebut bertujuan agar nilai-nilai yang terkandung di semboyan bangsa tidak tergerus oleh perkembangan zaman, terutama di zaman digital era 4.0. Oleh karena itu, perilaku-perilaku tersebut harus diaplikasikan di manapun dan kapan pun, hal ini bertujuan untuk mempertahankan eksistensi semboyan Bhinneka Tunggal Ika di era 4.0. tidak hanya dalam lingkungan masyarakat, adapun dalam dunia pendidikan di Indonesia, lebih menekankan pada pendidikan karakter yang dimiliki siswa. Pada kurikulum 2013, pendidikan karakter diterapkan pada semua mata pelajaran. Hal ini ditunjukan untuk mengembangkan aspek-aspek yang dimiliki siswa.

\section{DAFTAR PUSTAKA}

Akhyar, Zainul, dkk. (2015). Implementasi Toleransi Antar Umat Beragama di Desa Kolam Kanan Kecamatan Berambai Kabupaten Barito Kuala . Jurnal Pendidikan Kewarganegaraan. Vol.5. No.9.

Damanhuri, dkk. (2016). Implementasi Nilai-Nilai Pancasila sebagai Upaya Pembangunan Karakter Bangsa (Studi Kasus di Kampung Pancasila Desa Tanjung Sari Kecamatan Pabuaran Kabupaten Serang). Untirta Civic Education Journal. Vol. 1. No. 2.

Herawati, Y. (2014). Konsep Keadilan Sosial Dalam Bingkai Sila Kelima Pancasila. Vol. 18. No. 1.

Hermawan, I. (2019). Metodologi Penelitian Pendidikan Kuantitatif, Kualitatif dan Mixed Methode. Kuningan: Hidayatul Qur'an Kuningan.

Husna, A. (2012). Ketika Merasa Allab Tidak Adil Tips dan Trik untuk Bangkit dari Kegelisahan menjadi Insan Bahagia yang Penuh syukur. Jakarta: Gramedia.

Kementerian Pendidikan dan Kebudayaan. (2017). Buku Tematik Terpadu Kurikulum 2013 Buku Guru SD/MI Kelas IV Tema 6 Cita-citaku (Edisi Revisi). Jakarta: Kementerian Pendidikan dan Kebudayaan.

Kementerian Pendidikan dan Kebudayaan. (2017). Buku Tematik Terpadu Kurikulum 2013 Buku Siswa SD/MI Kelas IV Tema 6 Cita-citaku (Edisi Revisi). Jakarta: Kementerian Pendidikan dan Kebudayaan.

Kementerian Pendidikan dan Kebudayaan. (2016). Buku Tematik Terpadu Kurikulum 2013 Buku Guru SD/MI Kelas IV Tema 7 Indahnya Keberagaman di Negeriku (Edisi Revisi). Jakarta: Kementerian Pendidikan dan Kebudayaan. 
Kementerian Pendidikan dan Kebudayaan. (2017). Buku Tematik Terpadu Kurikulum 2013 Buku Siswa SD/MI Kelas IV Tema 7 Indahnya Keberagaman di Negeriku (Edisi Revisi). Jakarta: Kementerian Pendidikan dan Kebudayaan.

Lestari, G. (2015. Bhinnekha Tunggal Ika: Khasanah Multikultural. Jurnal Pendidikan Pancasila dan Kewarganegaraan. Vol. 28. No. 1.

Nengah, P. (2018). Implementasi Nilai-Nilai Bhinneka Tunggal Ika. Jurnal Pendidikan Sosial Keberagaman.Vol. 5. No. 1.

Neolaka Amos, dan Grace Amalia. (2017). Landasan Pendidikan Dasar Pengenalan Diri Sendiri Menuju Perubahan Hidup. Jakarta: Kencana.

Octavian, W. A. (2018). Urgensi Memahami dan Mengimplementasikan Nilai-Nilai dalam Kehidupan Sehari-hari sebagai Sebuah Bangsa. Jurnal Bhinneka Tunggal Ika. Vol. 5. No. 2.

Pursika, I. N. (2019). Kajian Analitik terhadap Semboyan Bhinneka Tunggal Ika. Jurnal Pendidikan dan Pengajaran. Vol. 42. No. 1.

Purwaningsih, E. (2012). Pentingnya Hidup Rukun. Jakarta: Balai Pustaka.

Puspita, Rianny dan Dikdik Baehaqi Arif. (2014). Implementasi Nilai-Nilai Bhinneka Tunggal Ika di SMA Muhammadiyah 5 Yogyakarta. Jurnal Citizenship. Vol.4. No.1.

Rafiah, D. (2017). Pengaruh Pengetahuan dan Sikap Terhadap Perilaku. Jurnal At-Tawassuth. Vol. 3. No.3.

Rizki, R. (2015). Mengenal Seni \& Budaya 34 Provinsi di Indonesia. Cibubur: Cerdas Kreatif.

Rosdalina. (2017). Hukum Adat. Yogyakarta: Deepublish.

Salim, M. (2017). Bhinneka Tunggal Ika Sebagai Perwujudan Ikatan Adat-Adat Masyarakat Adat Nusantara. Jurnal Al-Daulah.Vol. 6. No. 1.

Septiana, N. Z. (2019). Perilaku Prososional Siswa SMP di Era Revolusi Industri 4.0 (Kolaborasi Guru dan Konselor). Jurnal Nusantara Of Research. Vol. 6. No. 1.

Setyaningsih, U. (2019). Implementasi Nilai-Nilai Bhinneka Tunggal Ika Pada Siswa Kelas VII SMP Negeri Surakarta Pada Tahun Pelajaran 2016/2017. Jurnal Univetbantara.Vol. 1. No. 1.

Subagio, A. (2013). Go... Go... Indonesia 101 Alasan Aku Bangga Jadi Anak Indonesia. Jakarta: Cerdas Interaktif.

Susilowati, E, N. N. (2018). Merawat Kebhinnekaan Menjaga KeIndonesiaan: Belajar Dari Nilai Keberagaman Dan Kebersatuan Masyarakat Pulau. Jurnal Sejarah Citra Lekha.Vol. 3. No.1.

Sit, Masganti. (2017). Psikologi Perkembangan Anak Usia Dini. Depok: Kencana. 